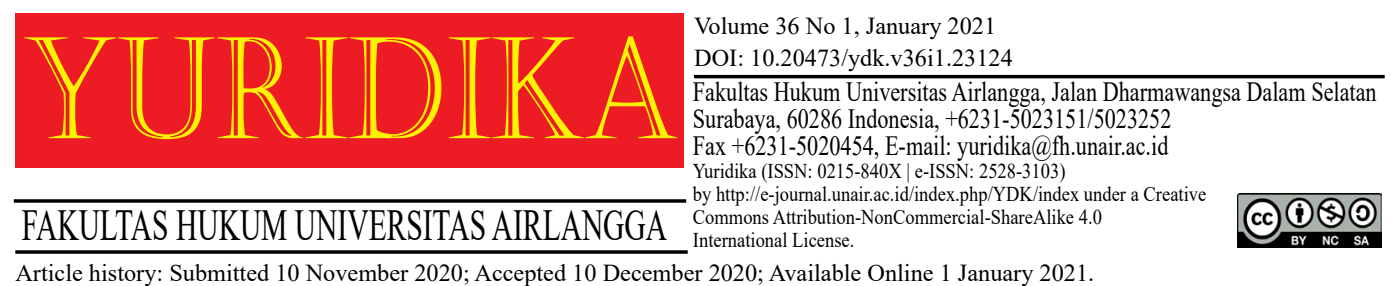

\title{
The Principle of Regulation of Mining License
}

\author{
La Sensu, Oheo K.Haris and Muhammad Nazar \\ lasensu@uho.ac.id \\ University of Halu Oleo
}

\begin{abstract}
The purpose of this study is to see and analyze the substance of a mining business permit regulation for the government to communities around mining and to find out and analyze the basic principles of a government policy to give birth to the welfare of communities around mining. This research used socio-legal research, which is a type of research whose orientation is focused on legal and non-legal aspects, namely the work of law in society and government. This revealed is that (1) the nature of Mining Business Permit Arrangements in regional autonomy has created euphoria among local governments, one of which is the assumption that mining belongs to the region and the local community; (2). Whereas the basic principle of the birth of a policy that does not pay attention to the welfare and interests of the local community will result in environmental damage, disharmony between residents, and the absence of commitment to building from mining entrepreneurs from the community around the mine.
\end{abstract}

Keywords: Principle; Mining; Regulation.

\section{Introduction}

Regulation is a rule and or norm in State administrative law. This relates to human nature or actions that are good and or not good. Furthermore, violating the law on policies of administrative authorities which are usually preventive at natural, and related to the prohibition of acting without permission. So that there is an opinion that the criminal law authority is to carry out investigations and further examinations will only be possible if other means (other law enforcement) have been attempted and failed. ${ }^{1}$

The government in the management of mining goods or materials which is one of the natural resources contained in the bowels of the earth or part of the earth's

${ }^{1}$ Oheo K.Haris, 'Criminal Law Aspect on Mining License' (2014) 29 Yuridika $<$ https://ejournal.unair.ac.id/YDK/article/view/376>. 
surface, which has a strategic value for human life, has strategic value because mining goods, especially oil and gas, affect the control of people's livelihoods. Besides, mining goods and materials have economic value so that they can improve community welfare. ${ }^{2}$

Mining goods or materials are one of the objects of natural wealth under the control of the State which are used to the maximum extent for the prosperity of the people. The concept of the right to control the State over natural resources in the bowels of the earth implies that the State is not the owner, but The state has more authority to regulate, guide, and supervise mining that will be carried out by the government. Mining activities need to be carried out, to obtain economic benefits for the value of mining goods/materials contained in the bowels/surface of the earth, therefore it is necessary to carry out a series of exploration and exploitation activities for mining materials/goods contained in the bowels of the earth or better known as mining.

The term mining in article 1 number 1 of Law Number 4 of 2009 concerning Mineral and Coal Mining is defined as: "Part or all of the stages of activities in the framework of research, management, and exploitation of minerals and coal which include general investigation, exploration, feasibility study, construction, mining, processing and refining, transportation and sales and post-mining". 3 Thus, the number of mining activity processes requires a form of supervision by the State. The mineral and coal mining sector is a form of non-renewable natural resources so that the amount is very limited while the need for mining goods/materials has a strategic value for the survival of the people at large. Therefore, the State, through the government, considers it important to take various policies to control activities. mining both at the exploitation stage to the post-mining stage.

\footnotetext{
${ }^{2}$ Oheo K.Haris,[et.,al.], 'Good Mining Practices Toward A Good Mine Management: A Case Of Mining Business Permit Issuance', The 2019 International Conference on Mining and Environmental Technology (IOP Publishing 2020).

${ }^{3}$ Law Number 4 of 2009 concerning Mineral and Coal Mining.
} 
The problems arising from the above background are what is the essence of the regulation of mining business permits for the government to communities around mining and how the basic principles of a government policy to give birth to community welfare.

This study aims to determine and analyze the substance of how the nature of the mining business permit arrangement for the government to the community around mining and to know and analyze the basic principles of a government policy to give birth to the welfare of the community around mining.

\section{The Nature of Licensing}

Licensing, ${ }^{4}$ a problem that is often a concern in everyday life, from ordinary people to officials, deals with licensing, because licensing is related to the interests that the public wants to carry out certain activities by obtaining approval or legality from state officials as an administrative tool in government of a country.

\section{Basics of Licensing}

$\mathrm{Law}^{5}$ is one form of norms or rules in life. The norms that regulate life include religious norms, morality, decency, customs, habits and laws. The relationship between the rule of law and other social norms is complementary, meaning that social rules govern human life in society even though the law does not regulate them. Besides complementing each other, it also strengthens each other. Even before the rule of law was codified, other rules already had their own clear rules and even had sanctions. The sources of religious norms, morality, courtesy and law differ. The source of religious norms is belief in God Almighty, norms of morality originate from the conscience, norms of decency are the source of the community's belief and legal norms are the source of statutory regulations.

\footnotetext{
${ }^{4}$ Muhamad Azhar,[et.al.], 'Building an Integrated Mining Licensing System in Order to Preserve the Environment in Indonesia', 1st SRICOENV 2018, E3S Web of Conferences (2018) $<$ https://www.researchgate.net/publication/329212118_Building_an_Integrated_Mining_Licensing_System_in_Order_to_Preserve_the_Environment_in_Indonesia $>$.

5 S.F Marbun, Indonesian State Administrative and $\bar{A}$ dministrative Court (UII Press 2003).[48].
} 
Licensing $^{6}$ in a broad sense is an approval from the authorities based on law. Permit in the narrow sense is exemption, dispensation and concession. The definition of permission according to the definition of the Indonesian Dictionary is $^{7}$ approval or statement of granting. Meanwhile, the term permit means to allow, allow, not prohibit. Broadly speaking, licensing law is a law that regulates public relations with the State in the event that a community requests a permit. Permit is an act of one-sided State Administrative Law which is applied in regulations based on requirements and procedures as stipulated in statutory provisions. Permits according to Bagir Manan are as follows: Permission is an approval from the authorities based on statutory regulations to describe certain actions or actions that are generally prohibited.

A special permit is: Agreement where it appears that there is a combination of public law with private law, in other words, a special permit is a deviation from something that is prohibited. Permission in question is, ${ }^{8}$ Dispensation is a declaration that is declaratory in nature, stating that a law does not apply to a case as filed by an applicant. License is a permit to do something that is commercial in nature and brings profit and profit. Concession is a stipulation of state administration juridically and complex, because it is a set of dispensations, permits, and licenses accompanied by the granting of some kind of government authority limited to the consistency. Concessions are not easy to give because of the many dangers of smuggling, land and natural resources of the country and sometimes they are detrimental to the people concerned.

Utrecht argued that a permit is when the making of regulations does not generally prohibit an act but still allows it as long as it is carried out as determined for each concrete thing, the act of the State administration allows the act to be a permit (vergunning).

\footnotetext{
${ }^{6}$ Muhamad Azhar.[et.,al], (n 4).

7 Big Indonesian Dictionary, Ministry of National Education (Raja Grafindo 2009).[142].

${ }^{8}$ Usman Ali Pratama, Licensing System Paradigm for Entrepreneurs (Djambat 2012).[24].
} 
Furthermore Prajudi Atmosoedirdjo ${ }^{9}$ is of the opinion that a permit is a stipulation which is a dispensation from a prohibition by law which then the prohibition is followed by details of the conditions, criteria and others that need to be fulfilled by the applicant in order to obtain a dispensation from the prohibition accompanied by a stipulation of procedures. and operational guidelines (implementation instructions) to the state administrative officials concerned.

Permission is an exception provided by law to demonstrate legality as a feature of a democratic constitutional state. Permits applied by state officials. Permission is: ${ }^{10}$ a. Concrete (the object is not abstract but tangible, certain and determined);

b. Individual (who is granted permission);

c. Final (a person has the right to perform a legal act in accordance with its content which can definitively give rise to certain legal consequences).

Regarding licensing in the realm of State administrative law that regulates it, because this law regulates the ways of carrying out the duties (rights and obligations) of the power of state equipment. State Administrative Law learns about licensing because permission is a relationship between the government and the community. Permission must be requested in advance from the person concerned to the Government through a procedure that has been determined by statutory regulations. ${ }^{11}$

One of the ways to establish a relationship between the community and the government is through interactions that exist in public services carried out by state administrative tools in carrying out services related to permit services. The relationship in the form of services provided can be a benchmark in assessing the merits of a form of service. If the community feels well served, then there is a distinct satisfaction value that can create a harmonious relationship between the government and its people. On the other hand, if the community feels disadvantaged in getting good service, then the community will feel uncomfortable and lose confidence in

\footnotetext{
${ }^{9}$ Astuti Aryanti, Guidelines for Entrepreneurs in Obtaining Business Licenses (Ghalia Indonesia 2009).[132].

${ }^{10}$ Muhamad Azhar.[et.al,] (n 4).

${ }^{11}$ Didin Rachmadi, State Administrative Law (Kharisma 2012). [83].
} 
the performance of the state administrative apparatus/tools, so that it can make the relationship between the community and the government not good. ${ }^{12}$

In the case of licensing, ${ }^{13}$ it is the administrative officer who has the authority to issue a permit, the relation is to the government's duty in providing public services to the community. In terms of services, a license is a form of service that must be provided to the public in the form of administrative services, namely services that produce various forms of official documents required by the public. Permits can be in the form of written and/or unwritten forms, but in State Administrative Law permission must be written, in relation if something happens that is not desired, then a permit in the form of a state administrative decision (beschicking) can be used as evidence in court. A license in the form of beschiking, of course, has concrete characteristics (the object is not abstract, but tangible, certain and determined), individual (who is granted permission), final (someone who already has the right to carry out a legal act in accordance with its contents which can definitively be give rise to certain legal consequences).

The elements in the permit are: ${ }^{14}$

1. The parties;

2. Object settings;

3. Ratification;

4. The issuing party;

5. Term (no license is valid for life);

6. What permission is used for;

7. Reasons for issuing permits; attribution, delegation and mandate.

Likewise, the compositions of a permit decision form are:

1. The name of the authorized organ;

2. The name of the addressee and the name of a certain object which is completed with the address;

3. Opportunities that give rise to a decision. Permits are generally applications;

4. An overview of the appropriate laws and regulations;

5. Determination of relevant facts;

6. Legal considerations;
12 ibid.
${ }_{13}$ Diana Halim Koentjoro, State Administrative Law (Ghalia Indonesia 2004).[28].
14 ibid.[7]. 
7. Decisions / dictums;

8. Motivation in the narrow sense;

9. Further notices;

10. Signing by authorized organs.

Permit ${ }^{15}$ is a government instrument in exercising control to achieve its goals. According to Ahmad Sobana, the licensing mechanisms and permits issued for administrative control and supervision can be used as a tool to evaluate the conditions and stages of development to be achieved, in addition to controlling the direction of change and evaluating the conditions, potentials and constraints that are touched to change. Furthermore, the objectives of the licensing system are ${ }^{16}$ among others, the existence of legal certainty, protection of public interests, prevention of environmental damage or pollution, and or equitable distribution of certain goods.

\section{Equilibrium Rules in Natural Resource Management Arrangements}

Exploration and exploitation of natural resources is characterized by a paradigm that assesses natural resources as a source of income rather than capital. This paradigm has been rooted long before the industrial revolution as a manifestation of the human desire to dominate nature, which should need each other to aim for a higher quality of life balance.

The implications of such a world view, consciously or unconsciously, have formed the mode of production of all economic activities, including exploration and exploitation of natural resources in mining, forestry and plantations. As far as is known, the exploitation of natural resources is still an elaboration of the paradigm mentioned above. Exploitation of natural resources that is only directed at supporting economic growth without proportionally paying attention to the preservation of environmental functions remains a general phenomenon. Even within certain limits the existence of natural resource management industries in an area, not only positions itself as an alien entity (alien entity) but also in many

${ }^{15}$ BachrulAmiq, Legal Aspects of Regional Financial Management Supervision (LaksBang, Pressindo 2010).[137].

16 ibid. 
cases is a source of social tempers. ${ }^{17}$ It is better if from the other side, the natural resource management industry, agriculture, forestry, fisheries, livestock and mining are the basic industries that support modern civilization. Specifically for the mining industry, without mining products in the form of metals and minerals, humans returned to the stone age, with caves and leather tents as shelters, wood as tools for digging the earth and hammers and stone axes as tools.

Modern civilization with tall buildings, vehicles, airplanes and thousands and even millions of equipment needed by humankind on a daily basis could not have been created without the use of metals and minerals. Examples ranging from planes, cars to cellphones, spoons and forks. How to imagine life without electricity: human activities are certainly very disturbed. ${ }^{18}$ To realize the goal ${ }^{19}$ of state control rights over mining natural resources, it can only be achieved if there is a power to exploit it through mining investment while still paying attention to the basic principles of exploiting natural resources, namely justice, prosperity and sustainability. From the various views above, as the basis for the formula for regulating the rules of balance in natural resource management, it reflects that the balance contains a deep meaning, namely the embodiment of the values of justice and morality (law and morality). ${ }^{20}$ Justice (fairness) is one of the legal goals sought and yearned by mankind. In regulating the management of mining natural resources, the content (het onderwep) of the laws and regulations should place the values of justice (equity), the value of sustainability (sustainability), the value of harmonization (harmonization) as the main consideration.

On the basis of the above values of justice, morality and legal principles, the regulation of mining businesses must pay attention to the balanced relationship between the state, region and society on the one hand, and limitations and harmonization between natural resources on the other. As it is known that the state is

\footnotetext{
${ }^{17}$ Abrar Saleng, Kapita Selekta Hukum Natural Resources (Grounded Publishing 2013).

18 ibid.[3].

19 ibid. [6].

20 ibid.; see Ronald Dworkin, Justice in Robes (The Belknap Press of Harvad University
} Press 2006). [45]. 
an intact structure or entity, natural resources including its mining potential belong to the state system as well as belong to the local order (province, and/or district/city and/or the lowest level) where the mining resource is located. . Utilization of mining resources and other natural resources must be able to proportionally improve the quality of the structure at each level. Because the quality of the orders is different or not the same, there is no constant formula that can be used to place the portion of the division that is acceptable to each arrangement, but is contextual.

In the absence of a fixed formula in determining the portion of both royality or production fees and compensation funds, partnership funds, communnity devolpment funds as part of corporate social responsibility (CSR), the only basic rules or rules that need to be enforced in the management of mining resources and natural resources must not diminish the chances of the local order in which resources are obtained to develop themselves. If the rule is applied in the management of mining natural resources, the exploitation of mining natural resources in a district can be interpreted as a reduction in the district's opportunities.

To build itself because it can be ascertained that its resources will decrease and decrease the quality of environmental functions. In accordance with the above principles, the loss of opportunities and the decline in environmental quality must be compensated by the provision and improvement of other resources that are at least capable of providing equal development opportunities. Below will explain the balance rule formula:

$$
\begin{gathered}
\text { The Equilibrium Rule Formula : } \\
\mathrm{TOR}=\mathrm{SR}+\mathrm{HR}+\mathrm{CR}+\mathrm{NR}+\mathrm{OR} \ldots \ldots . . . \mathrm{ER}
\end{gathered}
$$

Statement: ${ }^{21}$

TOR $=$ Total Order Resources

$\mathrm{SR}=$ Social Resources

HR $=$ Human Resources

\footnotetext{
${ }^{21}$ Abrar Saleng (n 17).See A. Mappadjantji Amien, Local Independence, Conceptions of Development, Organization and Education from a New Science Perspective (Gramedia Pustaka Utama 2005).[255].
} 
$\mathrm{CR}=$ Cultural Resources

$\mathrm{NR}=$ Natural Resources

$\mathrm{OR}=$ Other Resources

$\mathrm{ER}=$ Economic Resources

For this reason, ${ }^{22}$ the requirements for the validity of a license are that it must be in accordance with the spatial plan, public opinion as well as the considerations and recommendations of the competent official relating to the business and / or activity, the authority issued can be in the form of attribution, delegation, mandate.

The granting of authority or independence to state administrators in the HAN system is known as freies ermessen or discretionary power. The people in carrying out activities related to other communities, especially in terms of the economy, are not constrained by government policies that are not pro-people. People have a big share in running the economy on a micro and macro scale.

Policies in terms of the economy should not only accommodate the desires of the people who have capital, but the people who run the micro economy (which actually has more money in circulation there), also be considered proportionally. This becomes the basis of reference to be fought for, because it has been proven that during the monetary crisis, what could survive was the micro economy. The micro economy has taken root in the person of the Indonesian people based on the principles contained in Article 33 of the 1945 Constitution. Ideally, based on the 1945 Constitution, the economy is a people's economy, which focuses on the welfare of all the people, not a handful or a group of people..$^{23}$

The welfare of the community or not can be measured by the policies issued by the government (executive), legislative and judiciary. Policy alignments that are not proportional, can result in unequal distribution of welfare in society. In essence, the government as a public servant must prioritize the needs of society to be prosperous.

\footnotetext{
${ }^{22}$ Abrar Saleng (n 17).[9].

${ }^{23}$ Sujanto, Aspects of Supervision in Indonesia (Sinar Grafika 1996).[46].
} 


\section{Permit as a State Administrative Law Instrument}

The authority of the government, ${ }^{24}$ the legality and transparency principle becomes the basis for the legitimacy of government action and guarantees the protection of people's rights. According to Prajudi Atmosudirdjo, there are several requirements that must be met in the administration of government, namely: among others, Effectiveness, Legitimacy, Jurisdiction, Legality, Morality, Efficiency, Technique and Technology. In the Al-quran and Ash-Shunnah, the basic principles of governance are: inter alia, deliberation, equality and legal justice, social justice, freedom of expression, and protection of the souls and supervision of the people. Every state administration must have a principle of legitimacy, namely the authority granted by law, and the substance of the principle of legality is authority. ${ }^{25}$

On the other hand, IUP holders have the obligation to carry out management and monitoring of the mining environment, including reclamation activities, conservation of resources and reserves and handling of waste until mine closure. However, the provisions in the field of mineral resource conservation have not been further regulated in the form of legislation. Due to the absence of policy regulations regarding the management of minerals nationally, it has caused various conservation problems in general mining businesses. ${ }^{26}$

The calculation of resources and reserves generally only considers the economic aspects of the company ${ }^{27}$, the physical and chemical environment without considering conservation aspects, and their quantity can change according to economic and technological conditions. Therefore, the conservation aspect needs to be applied in the calculation of resources and reserves so that optimal and sustainable use is achieved. In order to avoid mistakes in calculation and abuse of rights to use resources and reserves, the government considers it necessary to issue a technical guideline

\footnotetext{
${ }^{24}$ Hadari Nawawi, Inherent Supervision in the Government Apparatus (Erlangga 1989).[17].

${ }^{25}$ Dian Purnama Anugerah and Yuniarti, 'Implementasi Prinsip Tranparansi Dalam Good Corporate Governance Melalui Peraturan Presiden (Perpres) No. 26 Tahun 2010 Tentang Transparansi Pendapatan Negara Diperoleh Dari Industri Ekstraktif' (2010) 25 Yuridika.

${ }^{26}$ Jimly Asshidiq, Concerning Law (RajaGrafindo 2011).[44].

27 ibid.
} 
for determining and supervising mineral resources and reserves which can become a reference for the Government and mining business actors.

Supervision of resources and reserves is carried out by the licensing ${ }^{28}$ agency in accordance with its authority, because the object of supervision includes maps of exploration results, results of laboratory analysis, data processing, methods of calculating resources/reserves, mining systems, mining recovery/processing, handling of grade minerals/low quality, handling of remaining reserves, handling tailings, and efforts to increase added value. Conservation problems related to reserve determination have been encountered in several mining business locations.

\section{The Principle of License Issued by the Government for the Rest of Social Interest}

Based on the results of the study through the concept of discussion of the results of this study, several things were found, including: The essence of an arrangement for a permit that is issued by the Government is for the benefit of the community, that a form of authority, of course, a permit must not conflict with statutory regulations and the existing norms of life in the community, both vertically and horizontally. Authority in the form of a license must reflect a policy that is by the life and convenience of the entire community so that the objectives of the state in the concept of a welfare state as set out in the fourth paragraph of the Preamble to the 1945 Constitution of the Republic of Indonesia can be realized. ${ }^{29}$

In the preamble of the 1945 Constitution to create a welfare state it has been mandated that: (1), the State is obliged to protect the entire Indonesian nation and the entire Indonesian territory, (2), the State must promote public welfare, and (3), the State must educate the nation's life.

A welfare state or welfare state is a country whose government ensures the implementation of the people's welfare. In realizing the welfare of its people, it

28 Suripin, Conservation of Soil and Water Resources (Andi Offset 2002).[14279].

29 Ganesha Patria Wicaksono, 'Kelembagaan Pengelola Minyak Dan Gas Bumi Pasca Putusan Mahkamah Konstitusi’ (2015) 30 Yuridika <https://e-journal.unair.ac.id/YDK/article/ view/4897/3588>. 
must be based on the five pillars of statehood, namely: Democracy, Rule of Law, protection of Human Rights, Social Justice (Social Justice), and anti-discrimination. The idea of a developing state welfare system in Indonesia is usually more negative than positive. For example, we often hear that the state welfare system is a wasteful approach, incompatible with economic development, and creates dependence on beneficiaries. As a result, not a few think that this system has met its default, aka no longer practiced in any country. Although this assumption is rarely accompanied by adequate arguments and research. many people have become less inclined to discuss, and take this approach into account.

The originator of the welfare state theory, Mr. R. Kranenburg, stated that the state must actively strive for prosperity, act fairly that can be felt by all people equally and equally, not for the welfare of certain groups but all the people. So it will be very careless if economic development is neglected, then economic growth is only viewed and concentrated on mere percentage figures. People's welfare is a real indicator.

Regarding licensing in the realm of State administrative law that regulates it, because this law regulates the methods of carrying out the duties (rights and obligations) of the power of state equipment. State Administrative Law learns about licensing because permission is a relationship between the government and the community. Permission must be requested in advance from the person concerned to the Government through a procedure that has been determined by statutory regulations.

One of the ways to establish a relationship between the community and the government is through the interactions that exist in public services carried out by state administrative tools in carrying out services related to permitting services. The relationship in the form of services provided can be a benchmark in assessing the merits of a form of service. If the community feels well served, there is a value of satisfaction in itself that can create a harmonious relationship between the government and its people. But on the contrary, if the community feels disadvantaged in getting good service, then the community will feel uncomfortable 
and lose confidence in the performance of the state administrative apparatus/tools so that it can make the relationship between the community and the government not good. In the case of licensing, it is the administrative officer who has the authority to issue a permit, the relation is to the government's duty in providing public services to the community. In terms of services, permits are a form of service that must be provided to the public in the form of administrative services, namely services that produce various forms of official documents required by the public.

Permits can be in the form of written and/or unwritten forms, but in State Administrative Law permission must be written, in relation, if something happens that is not desired, then a permit in the form of a state administrative decision (be checking) can be used as evidence in court. A license in the form of the best hiking, of course, has concrete characteristics (the object is not abstract, but tangible, certain, and determined), individual (who is granted permission), final (someone who already has the right to carry out a legal action following its contents which can definitively be given rise to certain legal consequences).

\section{The principle of a government policy is to create community welfare}

Whereas the principles of a government policy towards exploration and exploitation of natural resources are colored by a paradigm that assesses natural resources as a source of income rather than capital. This paradigm has been rooted long before the industrial revolution as a manifestation of the human desire to dominate nature, which should need each other to lead to a balance of a higher quality of life.

The implications of such a world view, consciously or unconsciously, have shaped the mode of production of all economic activities, including exploration and exploitation of natural resources in the mining, forestry, and plantations. As far as is known, the exploitation of natural resources is still an elaboration of the paradigm mentioned above. The exploitation of natural resources that is only directed at supporting economic growth without proportionally paying attention to the preservation of environmental functions remains a common phenomenon. 
Even within certain limits the existence of natural resource management industries in a region, not only positions itself as an alien entity (alien entity) but also in many cases is a source of social tempers.

It is better if, from the other side, the natural resource management industry, agriculture, forestry, fisheries, livestock, and mining are the basic industries that support modern civilization. Especially for the mining industry, without mining products in the form of metals and minerals, humans returned to the stone age, with caves and leather tents as shelters, wood as tools for digging the earth, and hammers and stone axes as tools. Modern civilization with tall buildings, vehicles, airplanes, and thousands and even millions of tools needed by humankind daily could not have been created without the use of metals and minerals. Examples ranging from planes, cars to cellphones, spoons, and forks. How to imagine life without electricity: human activities are certainly very disturbed. ${ }^{30}$

Based on the two contradictory realities above, the concept and business pattern of the agriculture and mining industry that produces foodstuffs for metal clothing, non-metal industrial minerals and coal as a source of energy, and geothermal energy in the future should be based on equity. balance (balances) and democracy (democracy) and sustainable (sustainable) involving between generations (intergeneration). ${ }^{31}$

These concepts and patterns can only be implemented well if they involve all stakeholders optimally in the form of partnerships. Meanwhile, the underlying mindset is social justice and equality, using a holistic, integrated, comprehensive, integrated approach, upholding pluralism, and having a long-term (sustainable) perspective. Now, we should not be proud of being a very rich nation because it has the potential of natural resources, especially natural resources that are not renewable (unrenewable resources), because our reserves are running low and

${ }^{30}$ PwC Indonesia, Mining in Indonesia Investment and Taxation Guide June 2019 (11th edn, Pwc 2019) <https://www.pwc.com/id/en/energy-utilities-mining/assets/mining/mining-guide-2019.pdf >

${ }^{31}$ Siti Kotijah, 'Pengaturan Hukum Pengelolaan Pertambangan Batubara Secara Berkelanjutan Di Kota Samarinda' (2012) 27 Yuridika <https://e-journal.unair.ac.id/YDK/article/view/287/152>. 
tend to run out. In regulating mining business permits, each mining company in carrying out its activities must meet the requirements for land ownership through a licensing process that has been determined by the prevailing laws and regulations. The regulations are:

Article 134 of Law Number 4 of $2009^{32}$ which stated:

(1) Rights to WIUP, WPR, and WIUPK do not cover the land surface of the earth,

(2) Mining business activities cannot be carried out in a place prohibited from carrying out mining business activities following the provisions of laws and regulations.

(3) Mining activities as referred to in paragraph (2) can be carried out after obtaining a permit from a government agency by the provisions of laws and regulations.

According to the author, every entrepreneur who carries out activities without paying attention to the applicable rules but is more obedient and obedient to the policies of a governor or regent/mayor has resulted in mining cases where many mining entrepreneurs put forward kinship, colleagues, and profit-sharing. between businessmen and officials in the regions and ownership of land rights has been manipulated. As a result, many communities around the mine have flocked to claim that the land belongs to their ancestors. For this reason, legal action is needed so that entrepreneurs are provided with an understanding of mining law through legal awareness training in each region or for each entrepreneur so that entrepreneurs and the government do not blame each other in case of legal problems. The right to control the state is an instrument (instrumental), whereas it is used for the greatest prosperity of the people as objectives. Overemphasizing, let alone merely seeing Article 33 as the basis for the state to control the earth, water, and natural resources contained therein is insufficient, it can even be misleading. Because the main element of the right to control by the state is to regulate and administer (regelen en besturen). Within the framework of this understanding, it can be said that controlling that state only performs bestuursdaad and does not perform eigensdaad. If there is a shift from bestuursdaad to eigensdaad, there is no guarantee for the maximum benefit of the people's welfare.

${ }^{32}$ Article 134 of Law Number 4 of 2009 Coal and Mineral mining. 
Based on this understanding, it is essential to always measure the implementation or implementation of the right to control the state to achieve the greatest possible prosperity for the people. To realize the goal ${ }^{33}$ of state control rights over mining natural resources, it can only be achieved if there is a power to exploit it through mining investment while still paying attention to the basic principles of exploiting natural resources, namely justice, prosperity, and sustainability. Management and utilization of late mining resources require a spatial management approach that is handled in a holistic integrated manner by taking into account four main aspects, namely, aspects of growth, aspects of equity, environmental aspects, and aspects of conservation. Such an approach requires the awareness that any mining activity will produce beneficial impacts as well as detrimental impacts on humankind in general and local communities especially if it is not managed professionally and responsibly.

\section{Conclusion}

That the nature of Mining Business Permit Arrangements in Regional Autonomy has created euphoria among Regional Governments, one of which is the assumption that mining belongs to the region and the local community. This euphoria has made it so easy for the local government to issue mining permits because it is to boost regional revenue (PAD) or increase regional financial capacity. However, what happens is the opposite, mining business activities benefit certain people more than the Regional Government.

Whereas the basic principle of the birth of policy results in environmental damage, disharmony between residents, and the absence of a commitment to build from mining entrepreneurs towards the communities around the mine. The problems that arise in the mining sector as mentioned above can be controlled through a licensing instrument. The government as the regulator will provide/determine certain conditions for every person or legal entity that will carry out mining business

\footnotetext{
${ }^{33}$ Abrar Saleng (n 17).[6].
} 
activities. If these requirements are not met, the mining business license cannot be issued. The essence of a license is a statement from the government to allow a person or legal entity to carry out certain activities with several conditions. Mining business permits issued by the government are legality if they are issued based on legal authority.

\section{Bibliography}

A. Mappadjantji Amien, Local Independence, Conceptions of Development, Organization and Education from a New Science Perspective (Gramedia Pustaka Utama 2005).

Abrar Saleng, Kapita Selekta Hukum Natural Resources (Grounded Publishing 2013).

Article 134 of Law Number 4 of 2009 Coal and Mineral mining

Astuti Aryanti, Guidelines for Entrepreneurs in Obtaining Business Licenses (Ghalia Indonesia 2009).

BachrulAmiq, Legal Aspects of Regional Financial Management Supervision (LaksBang, Pressindo 2010).

Big Indonesian Dictionary, Ministry of National Education (Raja Grafindo 2009).

Dian Purnama Anugerah and Yuniarti, 'Implementasi Prinsip Tranparansi Dalam Good Corporate Governance Melalui Peraturan Presiden (Perpres) No. 26 Tahun 2010 Tentang Transparansi Pendapatan Negara Diperoleh Dari Industri Ekstraktif' (2010) 25 Yuridika.

Diana Halim Koentjoro, State Administrative Law (Ghalia Indonesia 2004).

Didin Rachmadi, State Administrative Law (Kharisma 2012).

Ganesha Patria Wicaksono, 'Kelembagaan Pengelola Minyak Dan Gas Bumi Pasca Putusan Mahkamah Konstitusi' (2015) 30 Yuridika <https://e-journal. unair.ac.id/YDK/article/view/4897/3588>.

Hadari Nawawi, Inherent Supervision in the Government Apparatus (Erlangga 1989).

Jimly Asshidiq, Concerning Law (RajaGrafindo 2011). 
Law Number 4 of 2009 concerning Mineral and Coal Mining

Muhamad Azhar,[et.,al.], 'Building an Integrated Mining Licensing System in Order to Preserve the Environment in Indonesia', 1st SRICOENV 2018, E3S Web of Conferences (2018) <https://www.researchgate.net/ publication/329212118_Building_an_Integrated_Mining_Licensing_ System_in_Order_to_Preserve_the_Environment_in_Indonesia $>$.

Oheo K.Haris, 'Criminal Law Aspect on Mining License' (2014) 29 Yuridika $<$ https://e-journal.unair.ac.id/YDK/article/view/376>.

Oheo K.Haris,[et,.al], 'Good Mining Practices Toward A Good Mine Management: A Case Of Mining Business Permit Issuance', The 2019 International Conference on Mining and Environmental Technology (IOP Publishing 2020).

PwC Indonesia, Mining in Indonesia Investment and Taxation Guide June 2019 (11th edn, Pwc 2019) <https://www.pwc.com/id/en/energy-utilities-mining/ assets/mining/mining-guide-2019.pdf $>$.

Ronald Dworkin, Justice in Robes (The Belknap Press of Harvad University Press 2006).

S.F Marbun, Indonesian State Administrative and Administrative Court (UII Press 2003).

Siti Kotijah, 'Pengaturan Hukum Pengelolaan Pertambangan Batubara Secara Berkelanjutan Di Kota Samarinda' (2012) 27 Yuridika <https://e-journal. unair.ac.id/YDK/article/view/287/152>.

Sujanto, Aspects of Supervision in Indonesia (Sinar Grafika 1996).

Suripin, Conservation of Soil and Water Resources (Andi Offset 2002).

Usman Ali Pratama, Licensing System Paradigm for Entrepreneurs (Djambat 2012) 
--This page is intentionally left blank-- 